\title{
二三植物ノ發育特二其ノ新陳代謝二 及ボス日光ノ影響二關ス儿研究
}

第 3 回報告 日光/體內糖類(澱粉 $尹$ 含么)

会有量二及和ス影響

（本諭文，梗概公第 38 回岡山圈學會總會二テ表表 1927 。

岡山贯科大學生理學致室 (主任生沼票摱)

森川份

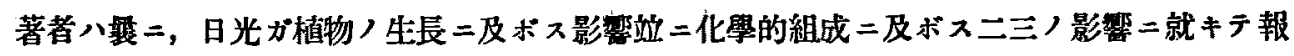
告スル所フリシカ，更二體內糖類含有量二及ボス日光ノ影謷二就キテ報告セントス。

\section{第 1 章緒 論}

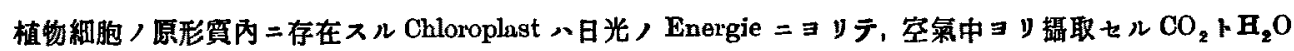

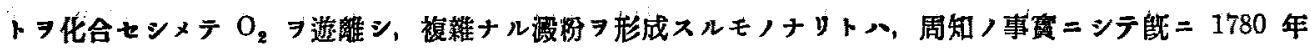

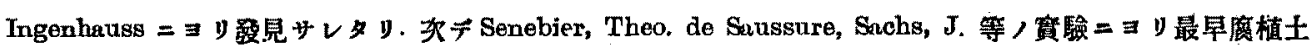
說 Humustheorie 八其, 影习絕ツニ至レリ。

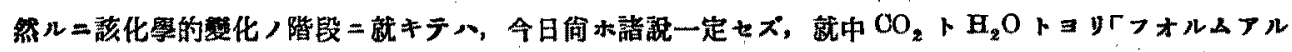

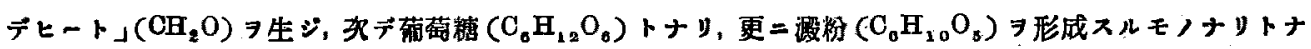

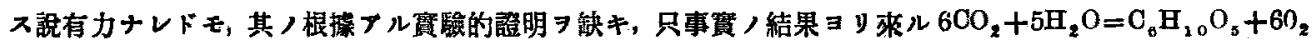

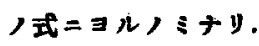

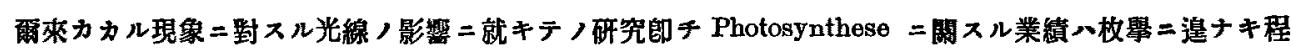

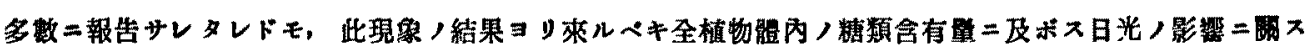
ル報告ハ之二反シテ非常ニ少數ナリ。

女 新

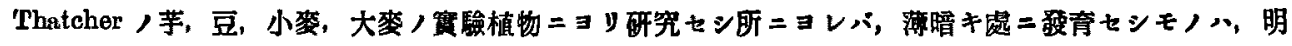

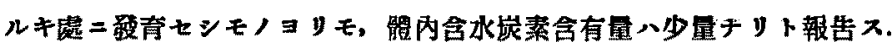

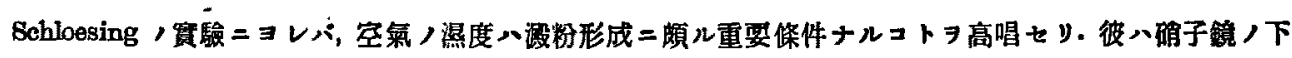

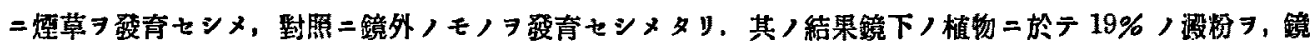

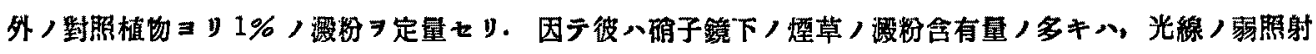

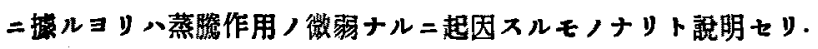

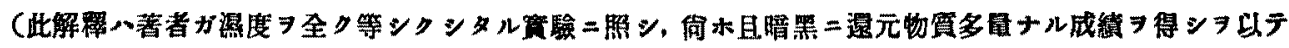
正當ナル解䁺ト直チニ思惟シ難シ.) 


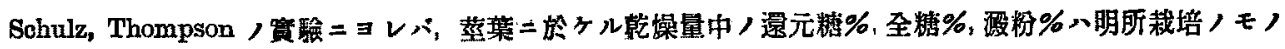

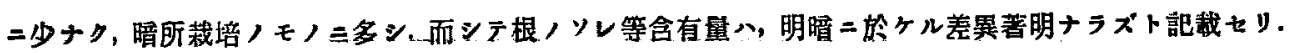

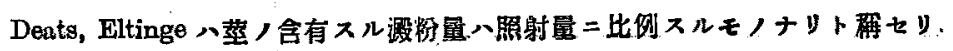

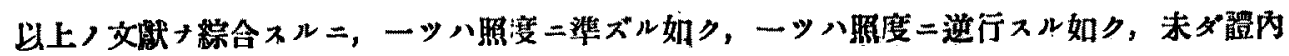

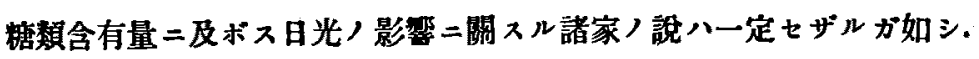

サレバ著者八此問题キ探究セント，炏ノ賽䲆タ企テタリ。

\section{第 2 章 實駼方法及ヒ其/成綪}

賽䮲方法八第 1 回報告第 2 章参照サレタシ.

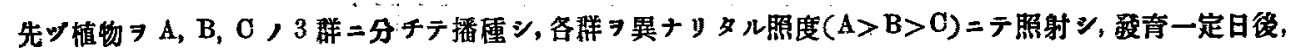

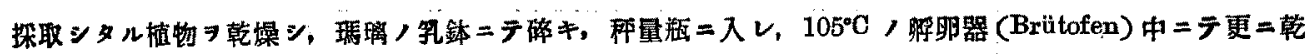

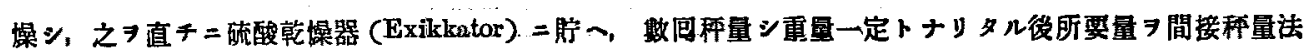

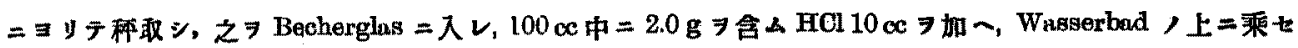

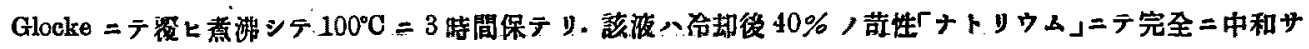

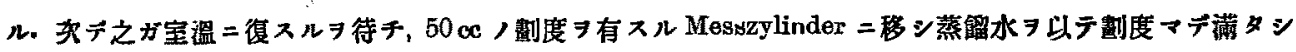

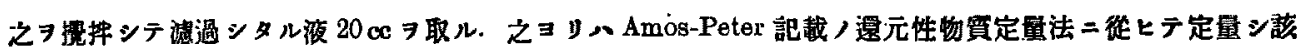

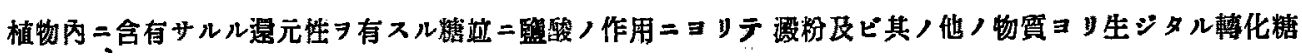

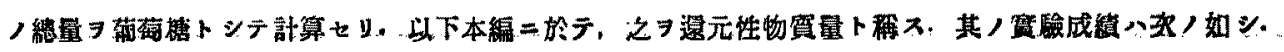

第 1 表

\begin{tabular}{|c|c|c|c|c|c|c|c|}
\hline 犗 & 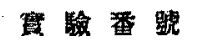 & $\cdot I$ & 11 & III & IV & $\mathrm{v}$ & 车均 \\
\hline \multirow[b]{2}{*}{ 度 } & 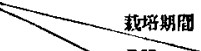 & $19 / \mathrm{III}-8 / \mathrm{TV}$ & $9 / \mathrm{IV}-5 / \mathrm{V}$ & $5 / \mathrm{V}-22 / \mathrm{V}$ & $23 / \mathrm{V}-20 / \mathrm{VI}$ & $21 / \mathrm{VI}-14 / \mathrm{VII}$ & 23 \\
\hline & 峄均含有 & 82.2 & 162.4 & 101.8 & 99.2 & 84.7 & 106.1 \\
\hline \multirow{3}{*}{$\mathbf{A}$} & 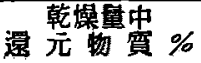 & 39.753 & 20.000 & & 14.187 & 18.265 & 23.051 \\
\hline & 酒告克物壱 \% & 7.517 & 3.206 & . & 1.474 & 1.800 & 3.499 \\
\hline & $\begin{array}{c}1 \text { 本中 } \\
\text { 元物䨘量 }\end{array}$ & 0.095 & 0.034 & & 0.052 & 0.055 & 0.059 \\
\hline \multirow{3}{*}{ B } & 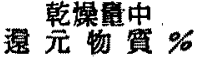 & 26.583 & 6.376 & 12.931 & 3.333 & 9.346 & 11.714 \\
\hline & 遑完犆物蛽％ & 2.908 & 0.526 & & 0.298 & 0.725 & 1.114 \\
\hline & 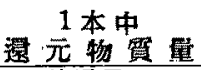 & 0.054 & 0.012 & & 0.005 & 0.011 & 0.021 \\
\hline \multirow{3}{*}{0} & 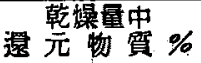 & 24.306 & & 9.527 & & 3.247 & 12.360 \\
\hline & 還芫物留 \% & 2.056 & & 0.541 & & 0.170 & 0.922 \\
\hline & 還元本中物富量 & 0.048 & ' & 0.016 & & 0.043 & 0.036 \\
\hline
\end{tabular}

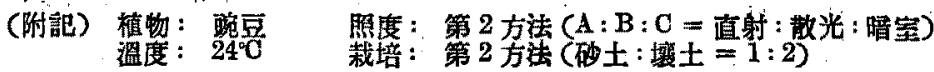


第 1 圆
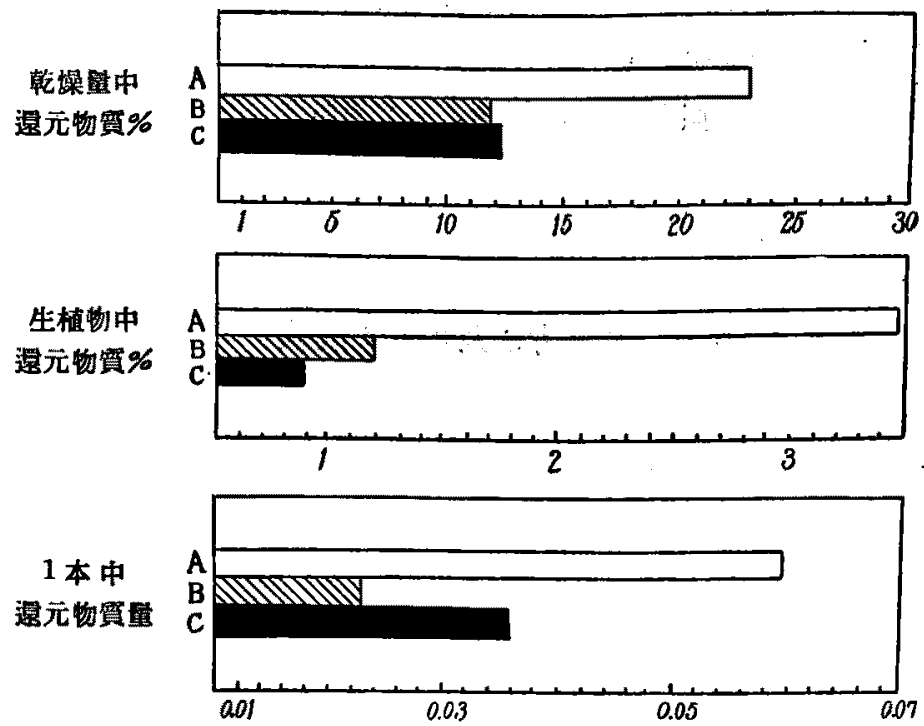

第 2 表

\begin{tabular}{|c|c|c|c|c|c|c|c|}
\hline 炤 & 蕒 瞼 番 號 & I & $\Pi$ & III & IV & $\mathbf{v}$ & 平均 \\
\hline 度 & 平均含有量 & $9 / 1-22 / 1$ & $22 / \mathrm{I}-8 / \mathrm{II}$ & $24 / \amalg-13 / \amalg$ & $18 / \mathrm{III}-4 / \mathrm{IV}$ & $29 / \mathrm{IV}-24 / \mathrm{V}$ & 17 \\
\hline $\mathbf{A}$ & 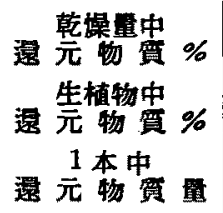 & $\begin{array}{r}15.625 \\
1.332 \\
0.023\end{array}$ & $\begin{array}{r}20.522 \\
1.757 \\
0.017\end{array}$ & $\begin{array}{r}23.606 \\
1.886 \\
0.044\end{array}$ & $\begin{array}{r}22.410 \\
2.102 \\
0.040\end{array}$ & $\begin{array}{r}12.500 \\
0.951 \\
0.016\end{array}$ & $\begin{array}{r}18.933 \\
1.606 \\
0.028\end{array}$ \\
\hline $\mathbf{B}$ & 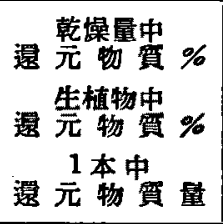 & $\begin{array}{r}34.439 \\
3.990 \\
0.036\end{array}$ & $\begin{array}{l}14.831 \\
1.191 \\
0.041\end{array}$ & $\begin{array}{r}22.309 \\
1.969 \\
0.035\end{array}$ & $\begin{array}{r}18.120 \\
1.402 \\
0.030\end{array}$ & $\begin{array}{r}16.827 \\
1.441 \\
0.014\end{array}$ & $\begin{array}{r}21.305 \\
1.999 \\
0.026\end{array}$ \\
\hline C & 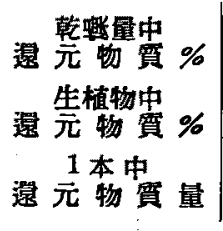 & $\begin{array}{r}29.290 \\
2.856 \\
0.042\end{array}$ & & $\begin{array}{r}26.931 \\
2.257 \\
0.056\end{array}$ & $\begin{array}{r}22.510 \\
1.755 \\
0.036\end{array}$ & $\begin{array}{r}18.523 \\
1.086 \\
0.025\end{array}$ & $\begin{array}{r}19.261 \\
1.591 \\
0.040\end{array}$ \\
\hline
\end{tabular}

(附部) 植物：踠豆照度：第3方法 $(A: B: C=9: 1: 0)$ 溫度： $240^{\circ}$ 栽培：第 2 方法(壤土 : 础土 $=2: 1$ ) 
第 $\quad 2$ 圖

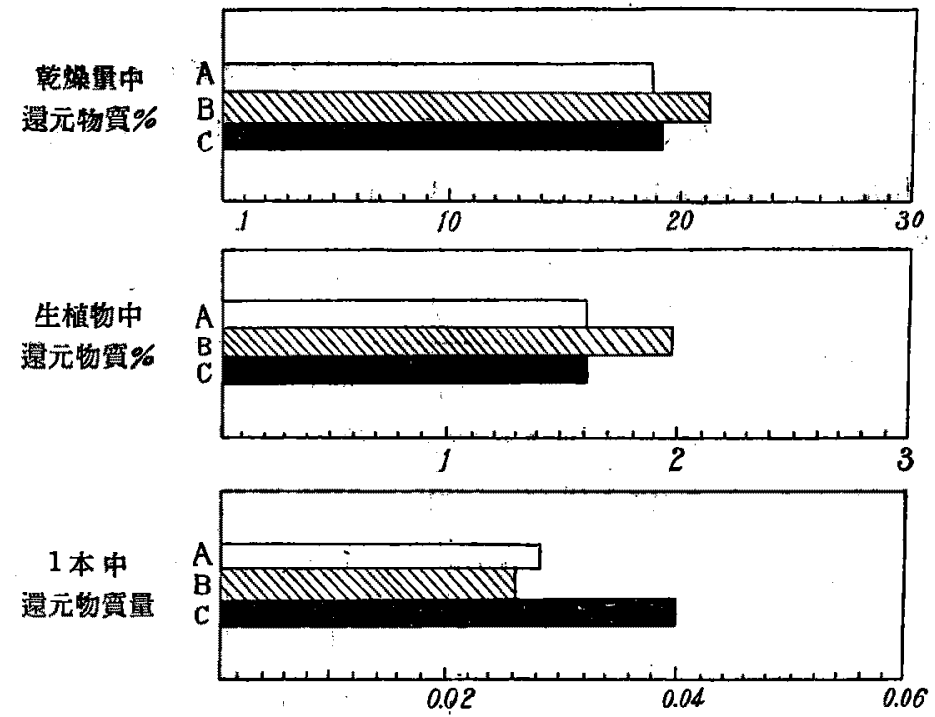

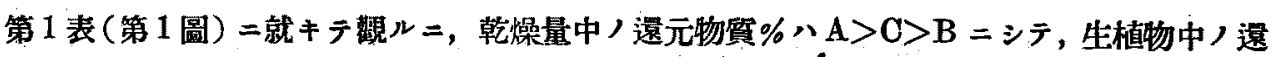
元物筫\% $\mathrm{A}>\mathrm{B}>\mathrm{C}+$ ・, 又 1 本中ノ本均遗元物質量 $\mathrm{A}>\mathrm{C}>\mathrm{B}$ ，關係キ示ス. 第 2 表二就 キテハ後述スベシ.

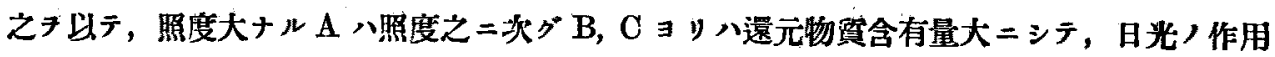

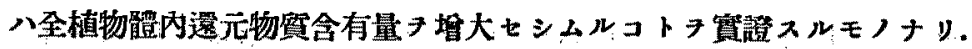

是レ Chloroplast，Photosynthesis 二關スル幾多研究者，成綪ヨリ來ルベキ結果二一致シ，

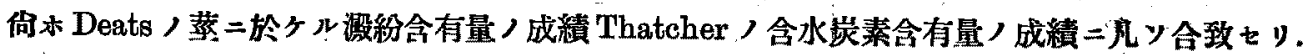

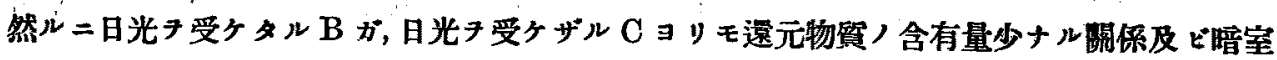

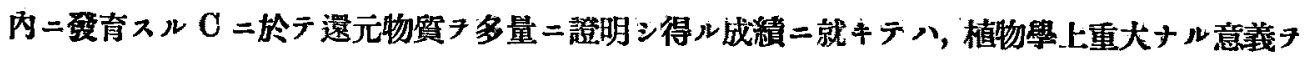

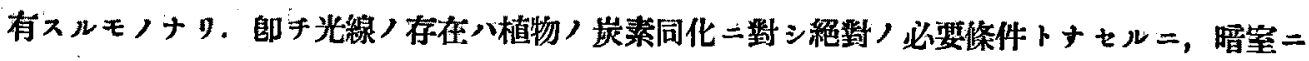
於テ斯ク多量ノ還元物筫フ含有スレバナリ。

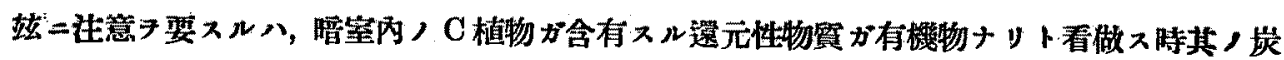

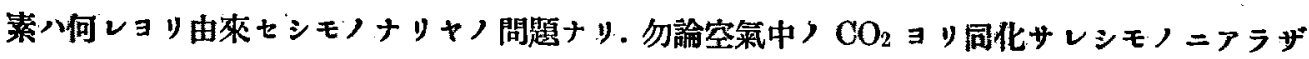

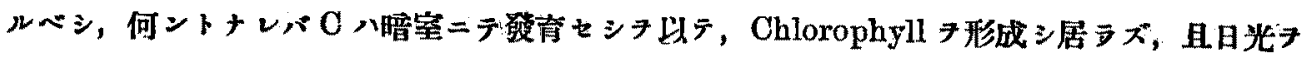

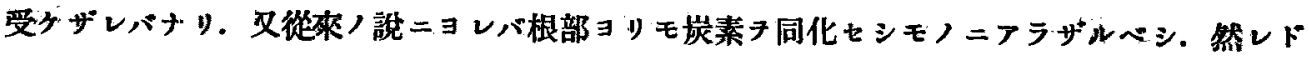
モ，最近 Molliard，Lubimenko 皮ビ Lefevre八研究ニヨレバ，炭素同化作用タナシ得ザル弱 光線照射ノ下 $=$ 於テ，地中二或ル炭素化合物ノ存在スルトキ小根部ョソ炭素习昅收同化シ得ル

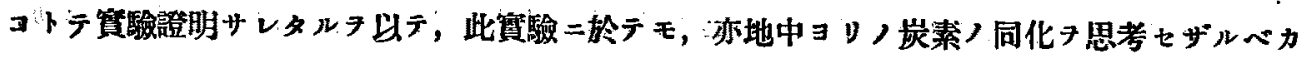
ラズ. 


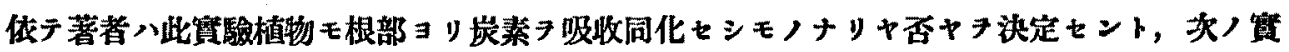
䐘タ繽行セリ.

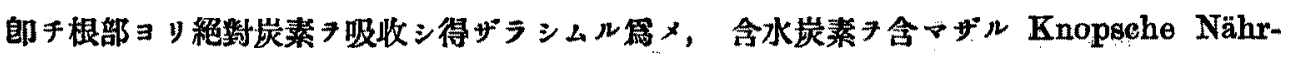

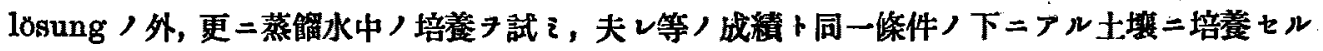

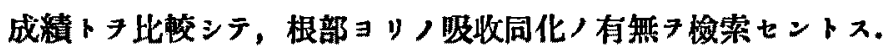

第 3 表ハ之等ノ諧成績

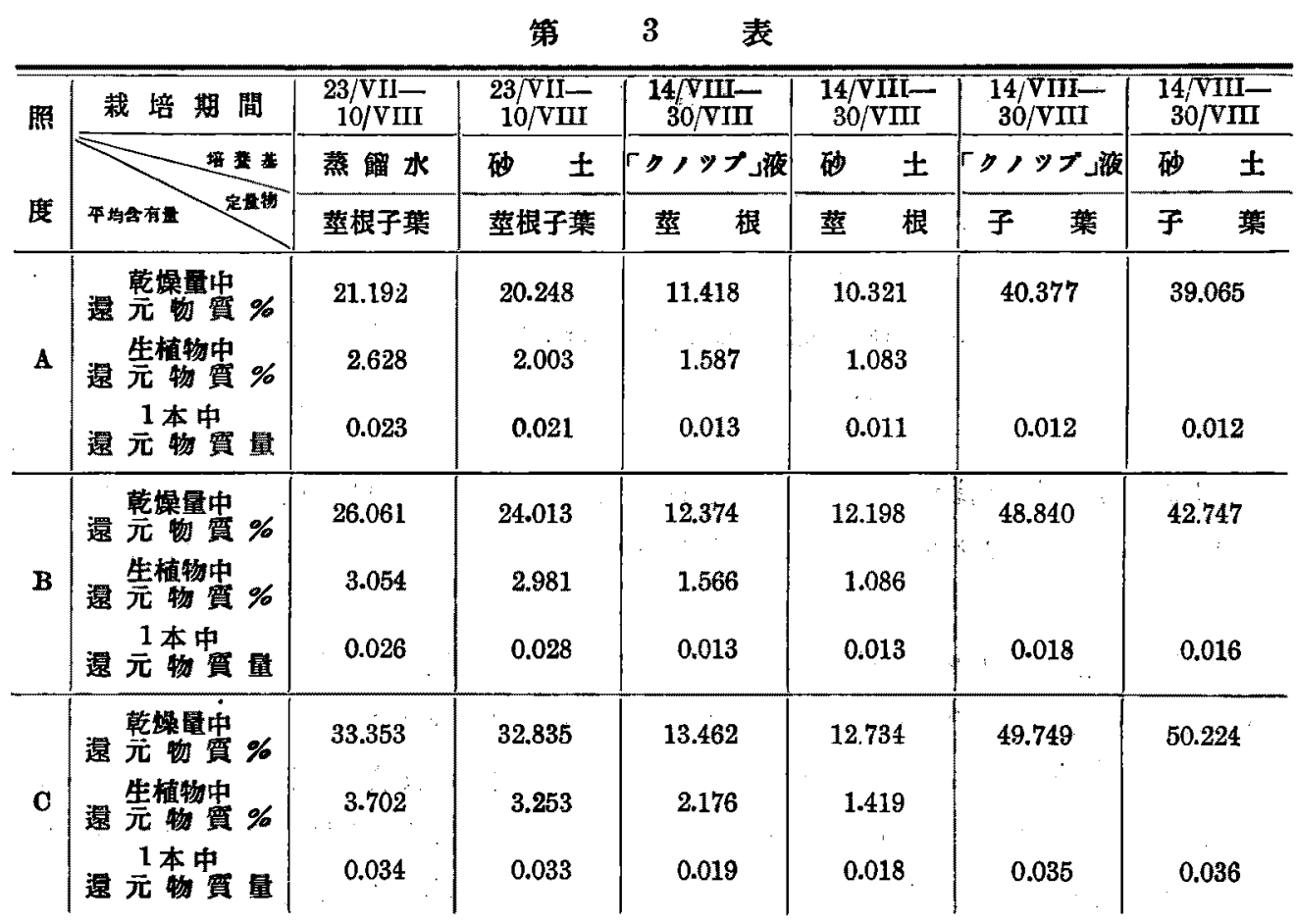

(附訅) 溻度：第 1 方法 $(A: B: O=100: 5: 0)$ ，植物：腕豆

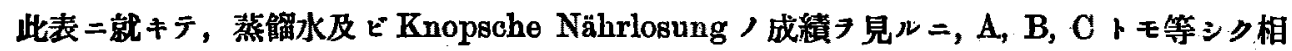

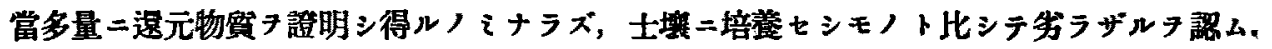

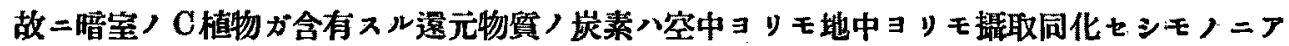

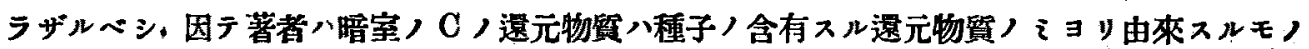

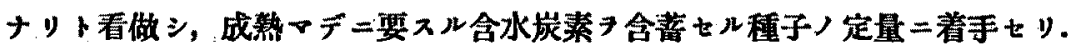

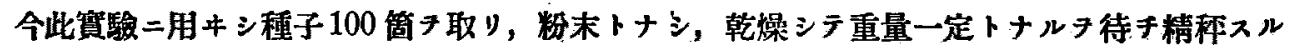

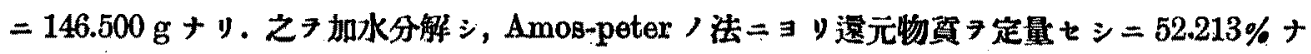

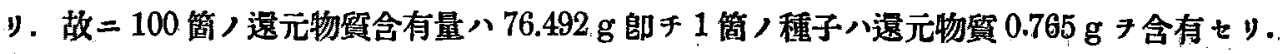

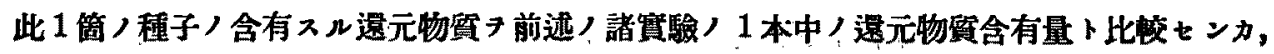
何レモ选二多量ナリ. 


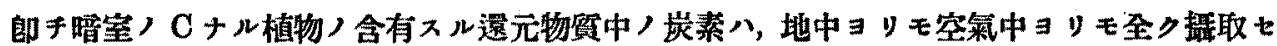

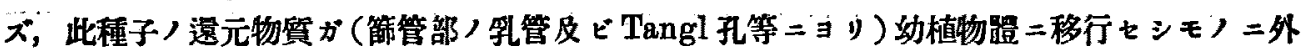
ナラズ.

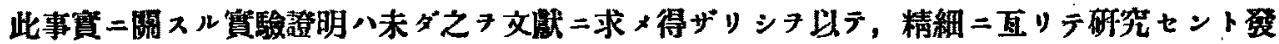

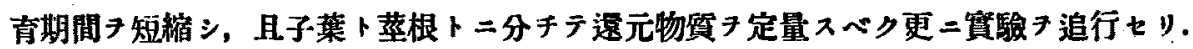

其) 筫驗成精

第 4 表

\begin{tabular}{|c|c|c|c|c|c|c|c|c|}
\hline 层 & 签 酹 番 跟 & III & $\mathbf{v}$ & VII & VIII & IX & $\mathbf{X}$ & 平均 \\
\hline 度 & 含有本岛㖖 & $27 / 1 \mathrm{~V}-7 / \mathrm{V}$ & $15, V-25 / \nabla$ & $15 / V-27 / V$ & $25 / V-5 / V$ & $25 / V-5 / V 1$ & $5 / \mathrm{VI}-15 / \mathrm{VI}$ & 10 \\
\hline \multirow{3}{*}{ A } & 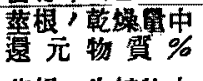 & 8.384 & 10.504 & 13.593 & 12.075 & 9.496 & 11.166 & 10,869 \\
\hline & 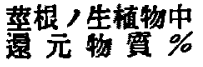 & 0.994 & 1.159 & 1.619 & 1.095 & 1.694 & 1.448 & 1.334 \\
\hline & 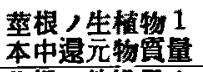 & 0.014 & 0.011 & 0.013 & 0.009 & 0.013 & 0.012 & 0.012 \\
\hline \multirow{3}{*}{$\mathbf{B}$} & 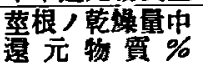 & 13.520 & 13.533 & 12.626 & 9.542 & 10.671 & 13827 & 12.286 \\
\hline & 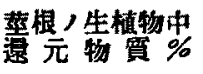 & 1.179 & 1.222 & 1.622 & 0.856 & $1.636^{\circ}$ & 1.442 & 1.326 \\
\hline & $\begin{array}{l}\text { 菜根，生槙物 } 1 \\
\text { 量 }\end{array}$ & 0.019 & 0.013 & 0.014 & 0.009 & 0.012 & 0.014 & 0.014 \\
\hline \multirow{3}{*}{$\mathbf{C}$} & 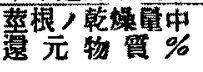 & 15.098 & 11.968 & 13.494 & 11.136 & 12.068 & 14.825 & 13.098 \\
\hline & $\begin{array}{l}\text { 覽根 光生植物中 } \\
\text { 貝 \% }\end{array}$ & 1.543 & 1.266 & 2.003 & 1.448 & 2.024 & 2.503 & 1.798 \\
\hline & 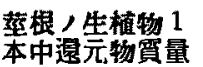 & 0.028 & 0.013 & 0.018 & 0.012 & 0.016 & 0.025 & 0.019 \\
\hline
\end{tabular}

（附訅）植物：磁豆 照度：第 1 方法 $(A: B: C=100: 5: 0)$ 溫度： $34^{\circ} \mathrm{C}$

第 3 圖
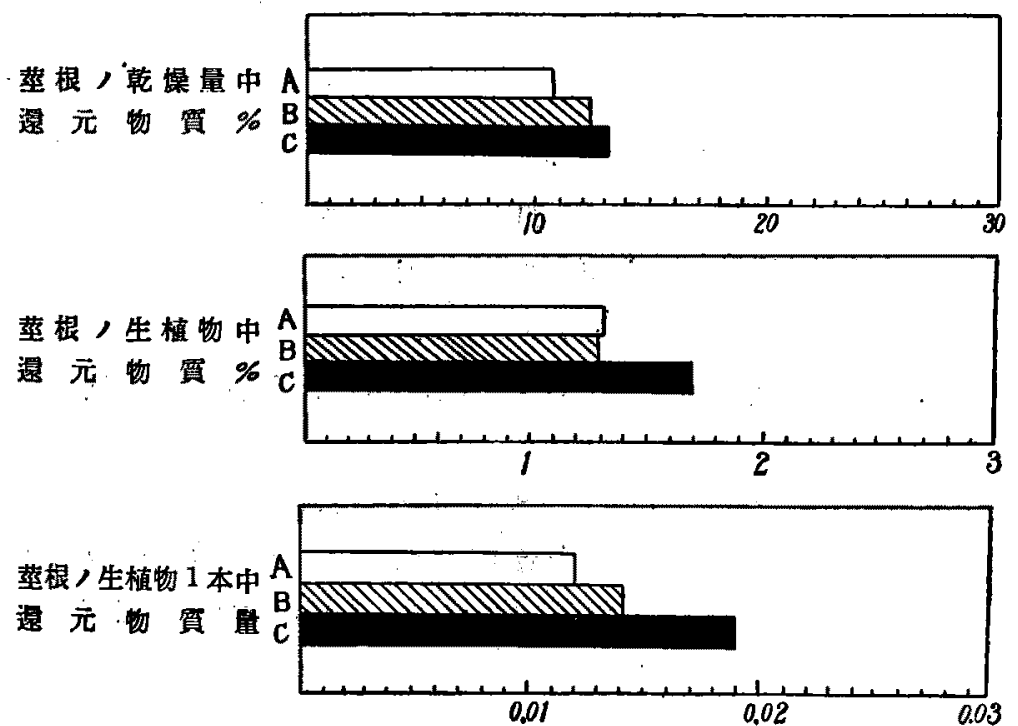
森川尚

第 5 表

\begin{tabular}{|c|c|c|c|c|c|c|c|c|}
\hline $\begin{array}{l}\text { 照 } \\
\text { 度 }\end{array}$ & 平均含有鱼 & III & V & VII & VIII & IX & $\mathrm{x}$ & 平均 \\
\hline \multirow{2}{*}{$A$} & 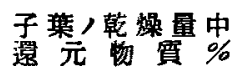 & 35.557 & 46.591 & 34.157 & 35.049 & 36.127 & 50.849 & 39.722 \\
\hline & 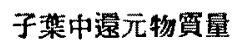 & 0.011 & 0.014 & 0.011 & 0.011 & 0.011 & 0.016 & 0.012 \\
\hline \multirow{2}{*}{ B } & 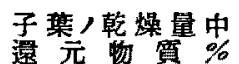 & 42.321 & 48.645 & 38.223 & 37.275 & 56.756 & 51.542 & 45.794 \\
\hline & 子葉中墖元物賀量 & 0.016 & 0.018 & 0.014 & 0.014 & 0.021 & 0.019 & 0.017 \\
\hline \multirow{2}{*}{ C } & $\begin{array}{l}\text { 搵芜乾焬量中 } \\
\text { 中 }\end{array}$ & 45.370 & 54.282 & 41.667 & 51.021 & 54.450 & 53.132 & 49.987 \\
\hline & 子葉中還元物圓量 & 0.033 & 0.039 & 0.030 & 0.037 & 0.039 & 0.038 & 0.036 \\
\hline
\end{tabular}

（附記）同上

第 4 圖
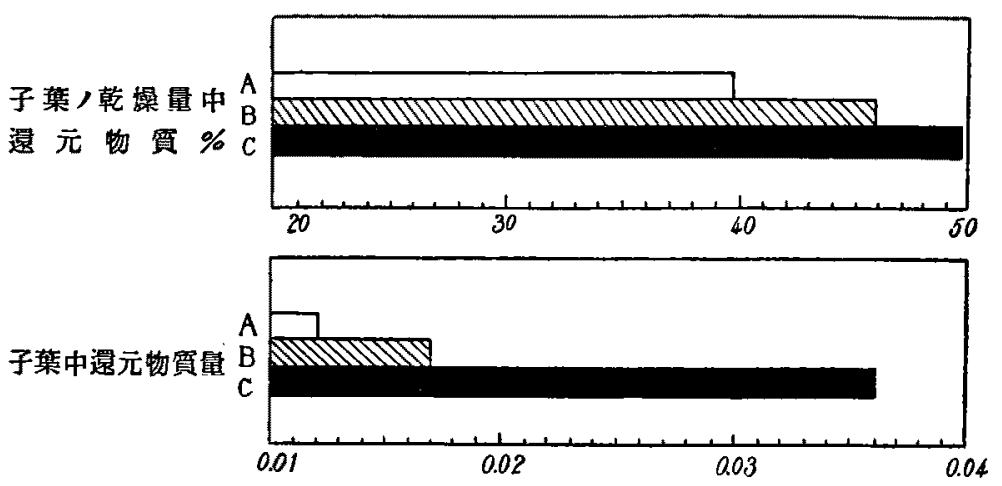

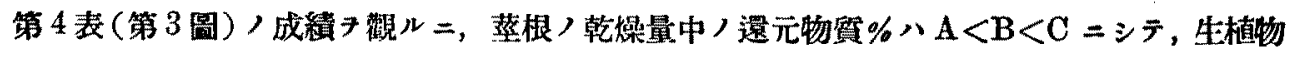

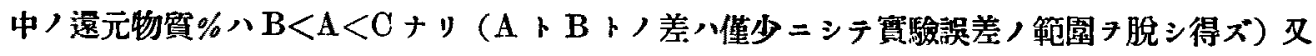

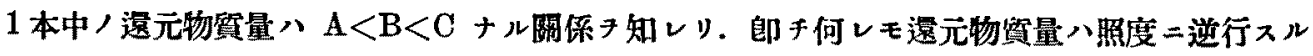

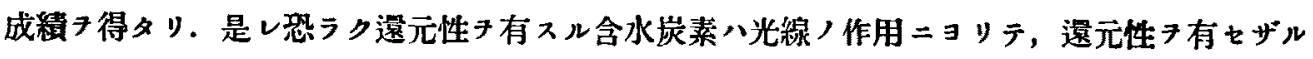
成分例へバ木織維ノ如キモノ二組成セラレタルニハアラザルカ。

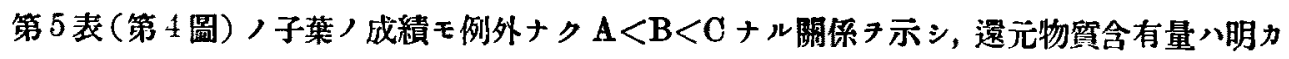
二照度二逆行 .

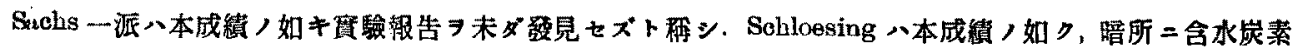

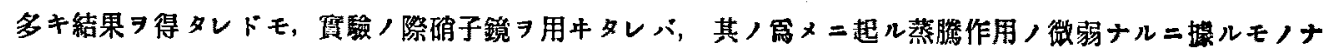

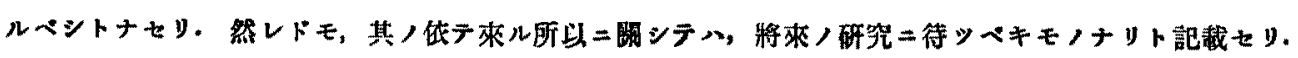

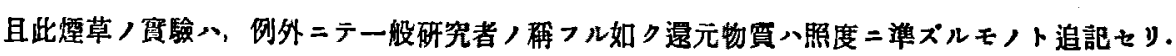




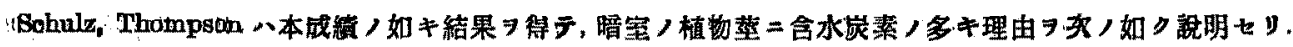

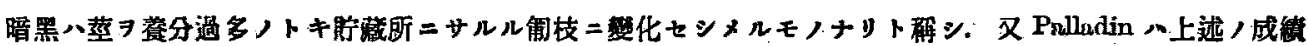

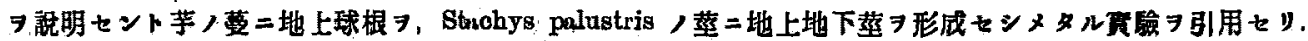

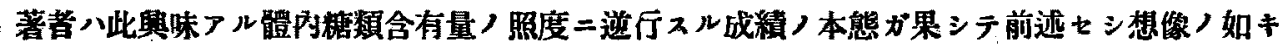
ヤ否ヤダ究メントス.

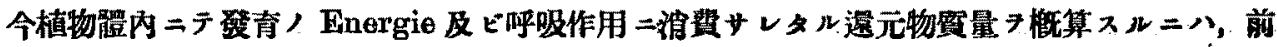

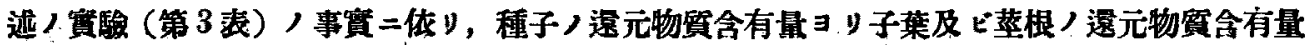
フ减ズパ㠹ナ、此結果テ第 6 表二表示セン。

第 6 表

\begin{tabular}{|c|c|c|c|c|c|c|c|c|}
\hline $\begin{array}{l}\text { 䑀 } \\
\text { 度 }\end{array}$ & 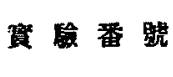 & III & $\mathbf{V}$ & VII & VIII & IX & $\mathbf{x}$ & 年 均 \\
\hline \multirow{2}{*}{$\mathbf{A}$} & 移行量 & 0.754 & 0.751 & 0.754 & 0.754 & 0.754 & 0.749 & 0.753 \\
\hline & 消 量 量 & 0.740 & 0.740 & 0.741 & 0.745 & 0.741 & 0.737 & 0.741 \\
\hline \multirow{2}{*}{$\mathbf{B}$} & 㱛行 量 & 0.749 & 0.747 & 0.751 & 0.751 & 0.744 & 0.746 & 0.748 \\
\hline & 消费量 & 0.730 & 0.734 & 0.737 & 0.742 & 0.732 & 0.732 & 0.734 \\
\hline \multirow{2}{*}{$\mathbf{0}$} & 移行量 & 0.732 & 0.726 & 0.735 & 0.728 & 0.726 & 0.727 & 0.729 \\
\hline & 消 费 量 & 0.704 & 0.713 & 0.717 & 0.716 & 0.710 & 0.702 & 0.710 \\
\hline
\end{tabular}

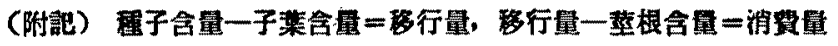

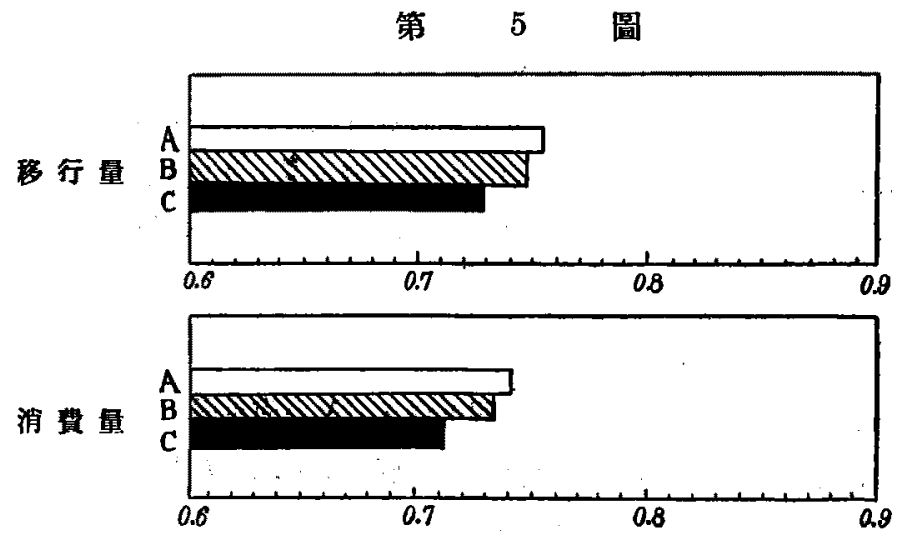

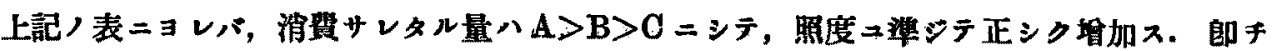

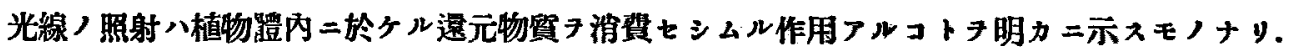

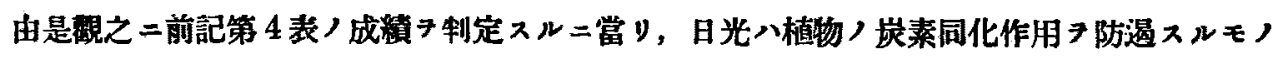

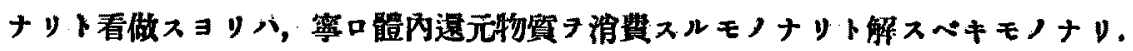




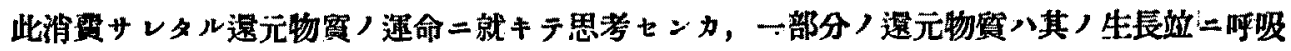

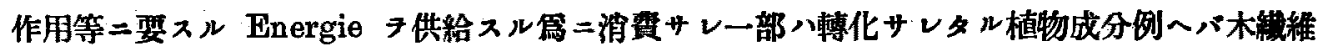

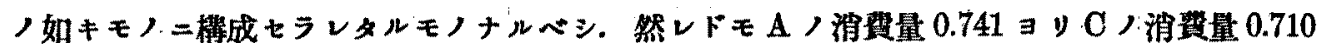

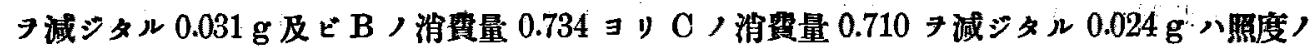

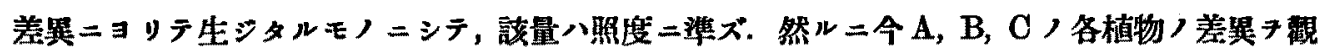

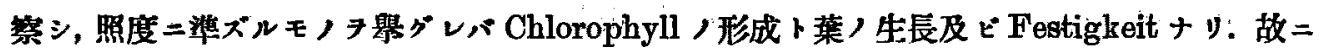

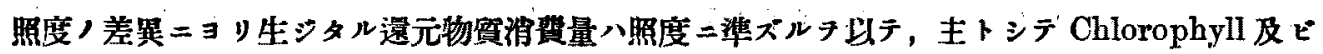
葉ノ形成二一部八其ノ非僄元性成分二消費サレタルモノト看做スへキモノナリ，余ハ之タ語セ

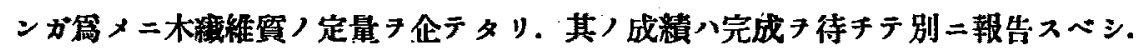

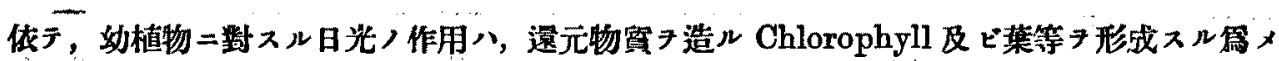

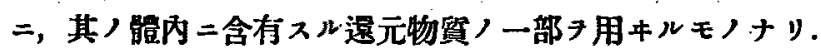

カカル日光ノ作用八落葉樹ノ春季發芽期二於ノル軆內糖数含有量 モノナルベシ.

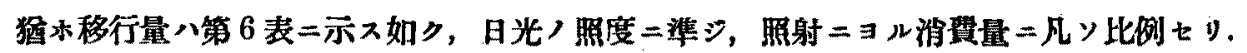

以上ノ諸事實キ發見セシかバ，著者ハ總括シテ再ビ全成績郎チ第 1 表，第 2 表及ビ第 4 表二 就キテ考安シ精迡スベシ.

第 1 表ノ退元物筫含有量ハ $\mathrm{A}>\mathrm{C}>\mathrm{B}$ ナル關係ナリ.

第 1 表八第 2 表，第 4 表二比シテ，照射日數長ク，且照度 $\mathrm{B}, \mathrm{C}=$ 比シテ大ナル $\mathbf{A}$ 八至賽驗

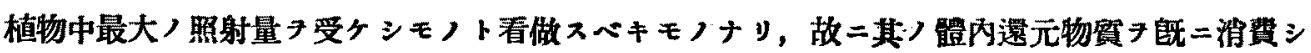

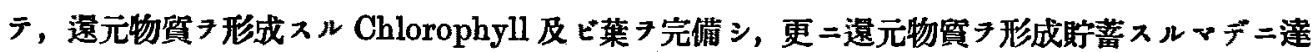
シタルモノフ探取シタル結果, 遇元物賢

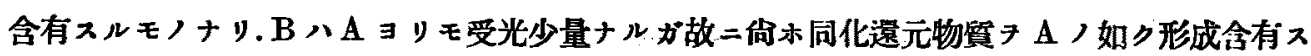

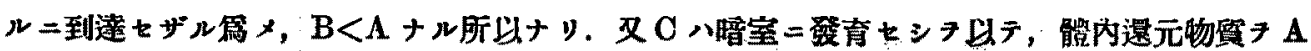

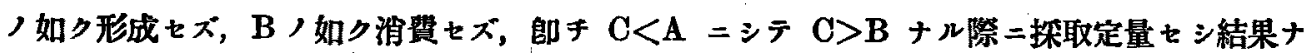
1).

第 2 表ハ $\mathrm{C}>\mathrm{A}>\mathrm{B}$ ナル成縝ナリ。

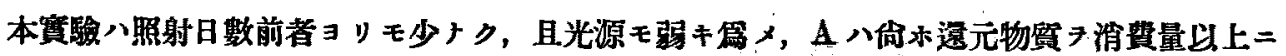

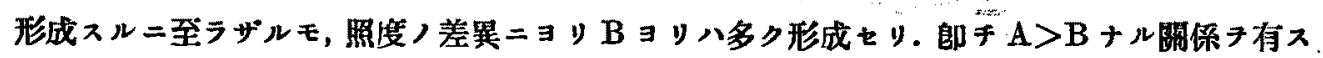

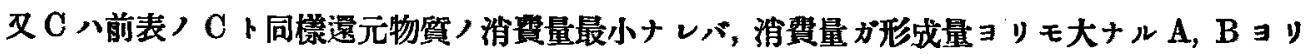
多ク保有シ, $\mathbf{C}>\mathbf{A}$ ニシテ, $\mathbf{C}>\mathbf{B}$ ナル關称トナレルモノナリ.

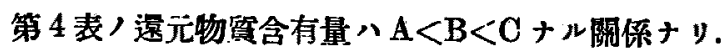

此筫驗り载培期間最モ短ク平均 10 日二テ探取定量七シモノナレバ，A，Bトモ未ダ榶類形成

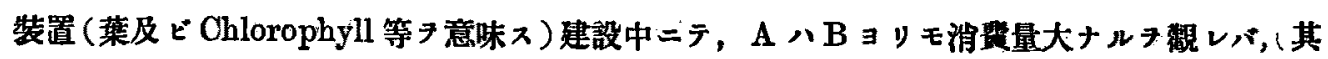




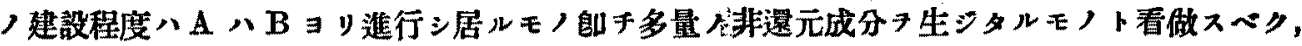

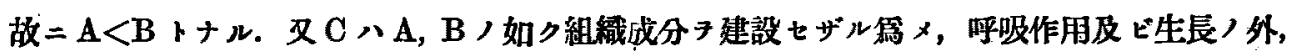

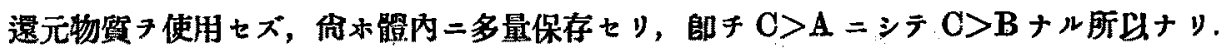

茲二於テ先人，交獻二見ユル，或八照度二準シ，或八照度二逆行スル由來 自ラ推知シ得へ シ.

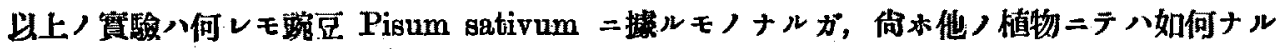

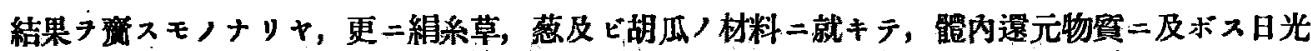

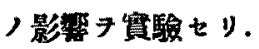

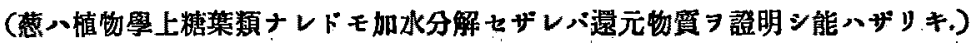
其/成縝八次厂如シ.

第 7 表

\begin{tabular}{|c|c|c|c|c|c|c|}
\hline 照 & 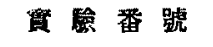 & VI & $\mathbf{X V}$ & XVIII & $\mathbf{x x}$ & IV \\
\hline & 成蓝物名 & 絹 系 草 & 綟 糸 草 & 葧 & 憼 & 胡 \\
\hline 度 & 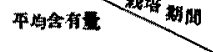 & $7 / 8-15 / V$ & $1 / \mathrm{IX}-14 / \mathrm{IX}$ & $30 / \mathrm{XI}-22 / \mathrm{XII}$ & $10 / \mathrm{I}-11 / \mathrm{II}$ & $6 / V-15 / V$ \\
\hline $\mathbf{A}$ & 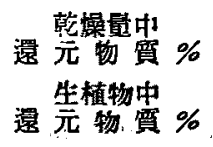 & $\begin{array}{r}18.333 \\
1.371\end{array}$ & $\begin{array}{r}12.182 \\
0.911\end{array}$ & $\begin{array}{l}4.524 \\
0.249\end{array}$ & $\begin{array}{l}6.132 \\
0.528\end{array}$ & $\begin{array}{l}5.988 \\
0.299\end{array}$ \\
\hline $\mathrm{B}$ & 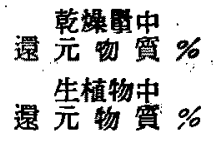 & $\begin{array}{l}18.072 \\
1.405\end{array}$ & $\begin{array}{c}14.241 \\
1.107\end{array}$ & $\begin{array}{l}6.018 \\
0.368\end{array}$ & $\begin{array}{r}5.582 \\
0.410\end{array}$ & $\begin{array}{l}1.279 \\
0.049\end{array}$ \\
\hline $\mathbf{C}$ & 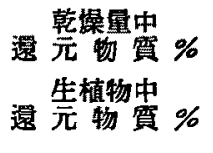 & $\begin{array}{r}35.526 \\
3.144\end{array}$ & $\begin{array}{r}16.729 \\
1.486\end{array}$ & $\begin{array}{l}6.147 \\
0.361\end{array}$ & $\begin{array}{l}6.067 \\
0.373\end{array}$ & $\begin{array}{l}6622 \\
0.281\end{array}$ \\
\hline
\end{tabular}

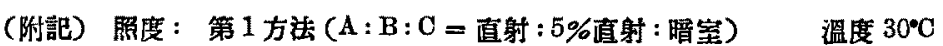
栽培法: 編糸草八綿 + Knop 氏釒液

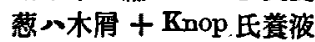

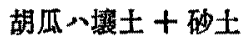

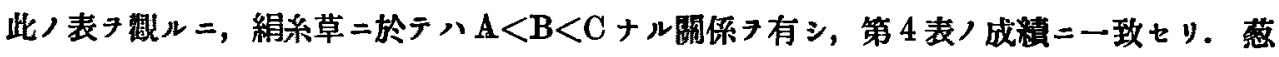

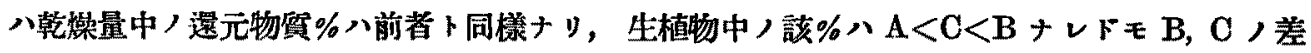

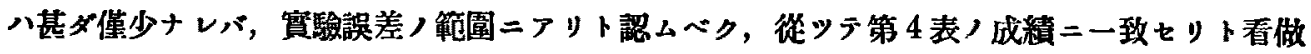

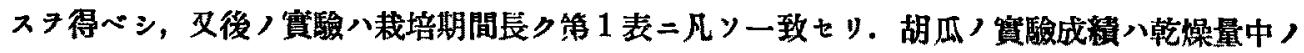

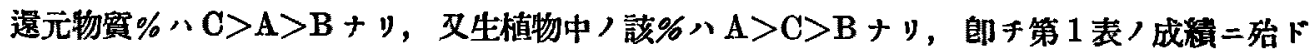

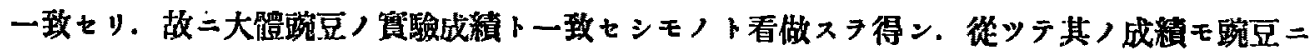
於タルト同榜二說明スルタ得. 
結 論

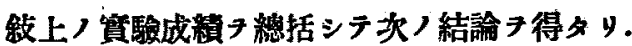

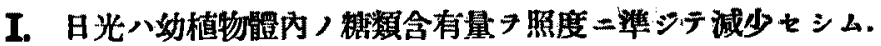

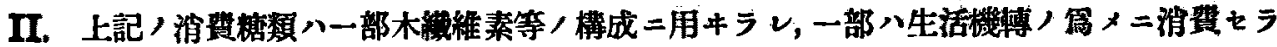
ルルモノノ如シ.

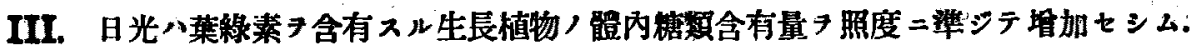

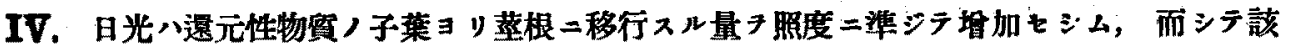
移行量八體內糖類ノ消費量二準ズ.

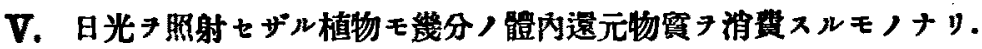

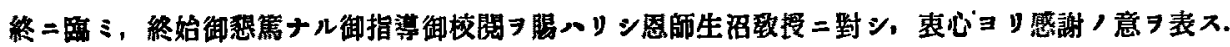

(3. 12. 14. 受稿)

\section{文 㩆}

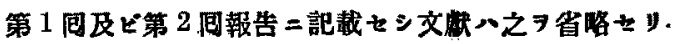

1) Bourquin, H., Bot. Gnz. 64. 1917. 2) Cole, S. W. Practionl physiological chemistry. P. 134. 1920. 3) Ewart. Jour. Linn. Soc. Bot. 1896.4 4) Fitting, H., Jahrb. f. wiss. Bot. 56, 1915. 5) Iwanoff, N. N., Biochem. Ztsohr. 182, S. 88, 1927. 6) Klein u. Pirschle, Bischem. Zeitschr. 176. 1926.

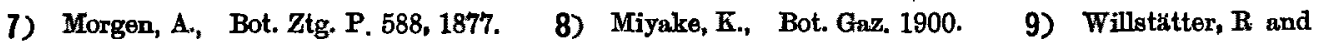
A. Stoll, Untersuchungen über die Assimilation der Kohlensăure. Berlin, 1918. 
Absoract.

\title{
Studies in the Influence of Sunlight upon the Development, and especially on the Metabolism, of certain Plants. \\ III. The Effect of Light on the Amount of invertable Carbo- hydrat of Pisum sativum and a few other plants.
}

By

\author{
Hisasi Morikawa. \\ From the Department of Physiology, Unizersity Okayana. \\ (Directer: Prof. S. Oinuma.) \\ Fecieved for publication, December 14, 1928.
}

The effect of sunlight on the amount of the invertable carbohydrat in Pisum sativum etc. was studied under three different light intensities as in the previous investigations. Dried tissue of each plant was hydrolyzed with 2 per cent $\mathrm{HCl}$ for 3 hours at $100^{\circ} \mathrm{C}$. Total amount of suger was determined by the Amos-Peter's methode The results of the experiment were as follows:

1. During the initial period of growth, the total amount of suger was in inverse proportion to the intensity of illumination,

2. But after the initial period the total amount of sugar in the plants was proportional to the light intensity.

3. Sugar substance appears to be synthetized to non-invertable substances like cellulose by light.

4. The results of the experiments on Allium ledebourianum, Phleum pratense $L$. and Cucumis sativus were almost the same to that of Pisum sativum. 